\title{
Strong Demands and Weak Institutions: The Origins and Evolution of the Democratic Deficit in the Philippines
}

Paul D. Hutchcroft and Joel Rocamora

N o country in Asia has more experience with democratic institutions than the Philippines. Over more than a century-from the representational structures of the Malolos republic of 1898 to the political tutelage of American colonial rule, from the cacique democracy of the postwar republic to the restoration of democracy in the People Power uprising of 1986-Filipinos know both the promise of democracy and the problems of making democratic structures work for the benefit of all. Some 100 years after the introduction of national-level democratic institutions to the Philippines, the sense of frustration over the character of the country's democracy is arguably more apparent than ever before. ${ }^{1}$ On the one hand, the downfall of President Joseph Estrada in January 2001 revealed the capacity of many elements of civil society to demand accountability and fairness from their leaders; on the other hand, the popular uprisings of April and May 2001-involving thousands of urban poor supporters of Estrada-highlighted the continuing failure of democratic structures to respond to the needs of the poor and excluded. Philippine democracy is, indeed, in a state of crisis.

In this article we will examine the country's current democratic deficit, that is, the enormous need for responding to pent-up demands and pressures from below, as well as the incapacity of the country's democratic institutions to do so with any degree of effectiveness. Although there are many ways in which this deficit might be filled, we argue that there is one crucial factor: the creation of more effective and cohesive political parties, oriented to programmatic rather than particularistic goals, policy rather than pork. Stronger parties can promote clearer choices to voters and help to structure political competition toward the realization of aggregate rather than particularistic interests. ${ }^{2}$ Because institutional deficiencies bear the bulk of the blame for the many histor- 
ical shortcomings of Philippine democracy, we argue, it is through institutional reform —of both representational and electoral systems- that the country can best begin to construct a democracy able to offer benefits to all. Building on the many strengths that already exist in Philippine democracy, the key task is to ensure that popular demands can be channeled more effectively through the reform of democratic institutions-in particular through the creation of stronger political parties. ${ }^{3}$

When we speak of a "crisis" of Philippine democracy, it is important to emphasize that the fundamental values of democracy continue to command broad respect from all sectors of Philippine society. ${ }^{4}$ The crisis is manifested, rather, in a deepening frustration over the inability of democratic institutions to deliver the goods, specifically goods of a public character. One can note the failure of political institutions to resolve the 2000-2001 crisis caused by the blatant corruption of the Estrada administration, a longstanding failure of the state to act on behalf of the public interest, extreme difficulties in controlling and regulating the means of violence (Lacaba 1995 and Sidel 1999), deeply rooted obstacles to converting the country's rich human and natural resources into sustained development (Hutchcroft 1998), and a general lack of responsiveness to the needs of the majority of the population. ${ }^{5}$

While Philippine democracy has major difficulties delivering goods of a public character, those with favorable access to the state have countless means of milking the system for private gain. Rentseeking activities tend to take place out of public view, but the phenomenon in general is widely acknowledged and breeds an increasing sense of cynicism with the practice of Philippine democracy. For ordinary citizens who derive few such benefits, explains economist Emmanuel de Dios,

government is an abstraction, an alienated entity, whose only palpable dimension is the episodic patronage dispensed by bosses and politicians, which merely reinforces the poor's real condition of dependence. This same alienated condition causes the electorate in many places to repeatedly elect convicted criminals, underworld characters, and known grafters, simply because such behavior is irrelevant to the more advantageous local clientelist functions those persons discharge, whether this be of a material nature (e.g., the local privileges [given to the First Couple's home regions] . . . under the Marcoses) or a symbolic one (e.g., Estrada's image as champion of the masses). (de Dios and Hutchcroft 2002)

At the same time, the failure of the state to deliver public goods leads many to seek to overturn the political system altogether. Alone 
among the countries of East and Southeast Asia, the Philippines has a by now more than three-decades-old communist-led insurgencyencouraged in large part by the immense gulf in levels of wealth and income between the elite and the millions of Filipino workers, urban poor, and peasants below them. In the south of the country, the Muslim minority has been in rebellion for most of this same period. These insurgencies have elicited countermeasures that have led to persistent violations of human rights and limits to the exercise of political rights by organized groups of the poor.

In the first section of this article we provide a historical overview of Philippine political parties in the American years, with particular emphasis on the early colonial era under William Howard Taft (1900-1913) and the Philippine commonwealth under Manuel Quezon (1935-1941). We shall locate the origins of Philippine democracy's institutional deficiencies in the early American colonial period and explore how the type of patronage-oriented party that emerged in the first decade of the twentieth century persisted in the midst of many changes-both in the scope of democratic politics and the structure of the overall political system. In the second section, we examine the continued evolution of patronage-oriented parties, from the emergence of a mass electorate in the early postwar years through the dictatorship of Ferdinand Marcos (1972-1986). In the third section, we examine the character of post-martial law democracy, focusing on how weak, patronage-based parties have endured under very different styles of presidential leadership: from the administration of Corazon Aquino (1986-1992) to that of Fidel Ramos (1992-1998) and Joseph Estrada (1998-2001). The fourth section examines the current crisis of democracy in the Philippines, focusing particular attention on the fall of Joseph Estrada and the rise of Gloria Macapagal-Arroyo in early 2001. In conclusion, we argue that the impending process of constitutional reform needs to begin with a clear understanding of the historical origins and evolution of the democratic deficit, then proceed to promote electoral and representational structures specifically geared toward the strengthening of Philippine political parties.

\section{The Origins of Modern Philippine Parties: Patronage Politics in the Colonial Era}

Following the conventional Western definition, the Philippine Omnibus Election Code of 1985 describes a political party as "an organized group of persons pursuing the same ideology, political ideas or platforms of government" (Leones and Moraleda 1998: 290). But nobody would 
accuse Philippine political parties of being such an animal. Carl Landé (1969: 156), perhaps the most influential student of Philippine politics in the last four decades, explains that "the two rival parties in each province ... are held together by dyadic patron-client relationships extending from great and wealthy political leaders in each province down to lesser gentry politicians in the towns, down further to petty leaders in each village, and down finally to the clients of the latter: the common [people]." Filipino sociologist Randolph David (2001: 24-25) describes political parties as "nothing more than the tools used by the elites in a personalistic system of political contests." Landé's and David's descriptions, it should be noted, are separated by some three decades, three constitutions, and by at least fourteen years of Marcos's dictatorial regime in the 1970s and 1980s. The period before Marcos's declaration of martial law in 1972 was marked by the dominance of two major parties, the period after 1986 , in what might be characterized as a multiparty system. But the parties themselves apparently remain much the same. Along with continuity, however, there has been significant change.

To understand the institutional deficiencies of modern Philippine democracy, one must begin with careful analysis of the institutional innovations of the early twentieth century. Prior to American colonial rule, it is important to note, the Philippines had no significant experience with national-level democratic institutions or national-level political parties. American colonials-building on the residual architecture of the previous Spanish colonial state and responding to a very widely supported revolutionary challenge-established the foundations of the modern Philippine polity. ${ }^{6}$ The key figure in the construction of American colonial rule is William Howard Taft, who between 1900 and 1913 (first as Philippine governor-general, then U.S. secretary of war, and later U.S. president) played a central role in the formulation of U.S. policy toward its largest colony. As part of Taft's so-called policy of attraction, the United States began to provide greatly expanded opportunities for political power to elites who had already developed a strong economic base throughout major regions in the latter decades of the Spanish era. Anxious to win over both a cosmopolitan ilustrado (educated) elite as well as a broader group of local caciques (chiefs) who had-particularly in the vicinity of Manila-given active support to the revolutionary effort, Taft and his associates drafted reforms that envisaged the creation of strong local governments and made longer-term plans for the convening of a national representative assembly (the promise of which was already formalized in the Organic Act passed by the U.S. Congress in 1902). 
There was nothing inevitable about this economic elite being transformed into a powerful political-economic elite; rather, this change came about through the very deliberate creation of new political institutions by the American colonial leadership. In other words, institutional rather than socioeconomic factors are most important to understanding the stature that this elite came to possess during the early American period (and which this elite has, indeed, enjoyed ever since). ${ }^{7}$ As Benedict Anderson explains, "It was above all the political innovations of the Americans that created a solid, visible "national oligarchy"' (1988: 11).

Although the efforts at "political tutelage" were proclaimed to be part of an effort to teach Filipinos the virtues of democracy, Taft and his fellow colonials made sure to limit the electorate to a very small, elite segment of the population based on the Americans' belief that "the masses are ignorant, credulous, and childlike" (May 1984: 46; Hayden 1942: 265, 267). In addition to limiting the rights of suffrage, the Americans actively discouraged any sort of popular mobilization that might threaten the political dominance of the elite. Even after the intensive military suppression of the Filipino-American war, nationalist groups could not organize themselves into parties because the Americans imposed an antisedition law declaring advocacy of independence a crime punishable by death (Banlaoi and Carlos 1996: 49).

Throughout their more than four decades of colonial rule, Americans steadily expanded the arenas of contention for Philippine elite politics. The indirect election of Philippine provincial governors by municipal officials was instituted in 1902 and was a significant innovation in Philippine politics. These elections encouraged the emergence of new and more extensive types of intraprovincial linkages and factions, and for the first time municipal politics became systematically tied into a larger network of provincial politics. ${ }^{8}$ This trend was furthered after 1906, when provincial governors came to be directly elected (by the elite electorate). As the American project of self-government moved beyond municipalities and provinces to the election of an assembly in Manila, these provincial factions became a major building block of national-level political maneuvering (Cullinane 1989: 227, 255, 513-514; see also Cullinane 2003). Thus one finds a political system that is at the same time highly restricted and rapidly expanding: the electorate remained confined to a small elite, but the opportunities provided to this elite for political contention were extended to increasingly higher levels of government.

The Philippines' first national-level political party emerged very early under American colonial rule. Founded in 1900, the Partido Fed- 
eral was an unabashed exponent of American rule at a time when guerrillas were still fighting against occupation (Banlaoi and Carlos 1996: 49). Political party formation is a not a normal activity for most colonial masters, but in the Philippines Taft considered it an important element of his larger project of "political education." He openly supported the Federalistas, not only giving them a privileged position on the Philippine Commission (the small, American-dominated body that advised the governor-general) but also providing ample opportunities for them to transcend their thin elite Manila political base and begin to build a larger following throughout the provinces. Most important, the Federalistas were given a powerful role in making appointments to key provincial offices (a privilege formerly enjoyed primarily by U.S. military officers) (Cullinane 1989: 90, 93-96; Salamanca 1984: 138).

By 1905, however, the Partido Federal that Taft had initially nurtured lost his active support-and thus lost its hold on provincial appointments. "Increasingly," explains Michael Cullinane (1989: 240), "the political forces in the provinces were playing their own games to gain access to patronage and political influence." Recognizing the limitations of relying on the Manila-based Federalistas, Taft put out instructions for colonial officials to look to provincial governors for a new group of Filipino leaders in order to "strengthen your hold on the entire archipelago" (Paredes 1989: 53-60, quotation at 60). Some did so with great skill and, in the process, promoted their own careers as well as the careers of the provincial elites whom they elevated to the national stage (Cullinane 1989: 413-429).

In 1907, the Philippine Commission began to share legislative power with the Filipino Assembly (elected by a highly circumscribed electorate through a U.S.-style single-member district plurality system). The leadership that emerged in the 1907 elections confirmed the shift toward provincial power that had become evident two years earlier. The leading provincial politicians, Sergio Osmeña of Cebu and Manuel Quezon of Tayabas, were the major figures in the newly formed Nacionalista Party, a purportedly pro-independence party that was to dominate Philippine politics for much of the next four decades. Together with others of similar background, they represented a qualitatively new type of national politician. Unlike the earlier group of Manila-based politicians who had become "solely dependent on American patronage," the new Nacionalista leadership enjoyed "a more permanent political base upon which to collaborate and compete with the colonial authorities." In contrast to many other provincial-based politicos, they had also been quick to see that it was possible to combine a provincial base with access to 
national power (Cullinane 1989: 389-390, 513-514, quotations at 514). The provincial elites-turned-national politicos elected to the assembly very deftly responded to the new opportunities created by American colonials and achieved a level of political authority able to obstruct the goals of the U.S. governor-general (May 1980: 57-73).

The Nacionalistas became in many ways the prototype for most subsequent twentieth-century Philippine political parties. While they consistently worked to consolidate their power at the national level, they were at the same time very responsive to allies in the provinces who desired a maximum degree of autonomy from colonial supervision. Because of their dominant role in the legislative leadership, the Nacionalistas can be described as a clear case of an "internally mobilized" party, defined by Martin Shefter (1994: 30) as a party "founded by elites who occupy positions within the prevailing regime and who undertake to mobilize a popular following behind themselves in an effort either to gain control of the government or to secure their hold over it."

In Shefter's framework, most "internally mobilized" parties will be patronage-oriented: because the parties occupy prominent roles within the regime, they have ready access to the patronage resources necessary to build a large following. There is one significant exception to the rule that an internally mobilized party will base its support on patronage resources, and that is the case of parties that have been established after the emergence of bureaucratic systems strong enough "to resist the depredations of patronage-seeking politicians." 9

Because colonial regimes tend not to create effective representative institutions, and instead put major emphasis on the creation of powerful bureaucratic systems, one would not anticipate that internally mobilized parties would emerge in colonial settings. The political institutions of the U.S. regime in the Philippines, however, are highly unusual in the annals of colonialism. First, contrary to their counterparts elsewhere, U.S. officials gave far more attention to elections and the creation of representative institutions than to the creation of a modern bureaucratic apparatus. Second, because U.S. colonials not only held elections for elite political contestation but also established representative institutions with significant degrees of political authority, one finds the bizarre phenomenon of internally mobilized parties in a colonial state. Third, because representative institutions emerged before the creation of strong bureaucratic institutions, "the depredations of patronage-seeking politicians" quite easily overwhelmed the Philippine bureaucracy. ${ }^{10}$ "As in the United States," explains Anderson (1988: 12), 
"civil servants frequently owed their employment to legislator patrons, and up to the end of the American period the civilian machinery of state remained weak and divided."

The Nacionalista Party was home to those politicians who had the greatest access to patronage resources and who demanded reforms, driven in large part by the desire for increased access to such resources. At the end of the Taft era, these demands included not only greater degrees of local autonomy but also increased control over government appropriations, tax reduction, weakening civil service provisions, the Filipinization of the bureaucracy and cabinet posts, a quasi-parliamentary system of government (so that Nacionalista legislators could simultaneously assume cabinet posts), and the creation of an elected senate to take the place of the Philippine Commission. As the ideological divisions over how to respond to American colonialism receded into the past (see Cullinane 1989: 515-518), the logic of Philippine politics became driven to a very considerable extent by the politics of patronage: dividing the spoils among the elite and expanding the quantity of spoils available to the elite as a whole. In effect, American colonials successfully diverted the revolutionary quest for self-government into a simultaneous quest for increased local autonomy, expanded national legislative authority, and more extensive opportunities for patronage.

After 1913, as the goal of Philippine independence was given enthusiastic support by a Democratic governor-general, arenas for elite political contestation expanded further, and the political reforms urged by the leading Nacionalista politicians at the end of the Taft era were to a large extent adopted. When the Philippine Commission was replaced by the Senate in 1916, American colonials removed themselves entirely from the legislative branch of government. Governor-General Francis Burton Harrison "deliberately surrendered initiative to elected officials," leading to "an increasing measure of control over the executive departments and even the judiciary." Filipinization of the bureaucracy was rapidly accelerated, and all members of the cabinet except one were Filipino citizens. In 1918, the governor-general created the Council of State in which he shared executive authority with major legislative leaders, notably House Speaker Osmeña and Senate President Quezon (Stanley 1974: 252-254, quote at 252). Harrison did little to oversee the cabinet, and it was an Osmeña ally who assumed the cabinet post responsible for supervision of local governments as well as the Philippine constabulary. Broad control over appointments and budgets gave the Nacionalista party leaders strong patronage links with the bureau- 
cracy. With the creation of the Philippine National Bank, a "cornucopia of easy credit" and "vehicle for patronage," tens of millions of dollars from various sources (including $\$ 41$ million from the currency reserve fund in New York) were lent to those with favorable connections (Stanley 1974: 239-248, 254-255 quote at 240; Hutchcroft 1998: 66-69).

When Leonard Wood, the former general, become governor-general under a new Republican administration in 1921, he immediately set out to reassert executive authority. His relations with the legislature were often contentious as the two branches of government engaged in frequent tussles over taxes, expenditures, and appointments: while Wood promised to uphold representative government, he regularly deployed his veto power against the legislature. When Quezon declared that "the policies of the government should be dictated by the Legislature as embodied in definite laws and acts of that body," Wood denounced Quezon for "trying to seize power that did not belong to him." Wood enjoyed the solid support of the Coolidge administration back in Washington, but on crucial issues neither the U.S. Congress nor the Supreme Court cooperated with efforts to bolster the authority of the governorgeneral. In sum, one can say that while Wood did much to strengthen his office after the diminution of its powers under Harrison, the Philippine legislature continued to be a major check on the authority of the American colonial executive. Meanwhile, after a major political showdown between Quezon and Osmeña in the early 1920s, Quezon emerged as the dominant figure for the remainder of the colonial era. ${ }^{11}$

Ironically, it was through a major step toward decolonization-the creation of the Commonwealth in 1935-that largely uncontested executive authority emerged in the colony. The new constitution, drafted mainly by Nacionalista party delegates, accorded Quezon, the commonwealth president elected in 1935, a potent range of powers in both the legislative and executive spheres. ${ }^{12}$ As Emiliano Bolongaita explains, the very substantial executive powers of the governor-general "were almost literally transferred, with little contest, to the Philippine presidency by the drafters of the 1935 constitution" (Bolongaita 1996: 85). In addition to acquiring these formal powers, it must be noted that Quezon enjoyed a major advantage over the governors-general who had previously occupied the palace: through skillful dispensing of government resources, he was able to achieve considerable control over the Nacionalista party members that dominated the one-house legislature. Perfecting techniques that had emerged over the previous thirty years, Quezon centralized access to patronage and built what was arguably the strongest political party in Philippine history. As in earlier decades, 
however, the party remained thoroughly nonideological. "The political battles of [Quezon's] time were fought ... for factional power and personal leadership," an associate later recalled. "In those circumstances a political philosophy was unnecessary; it might even be a disadvantage" (Recto 1953: 392). In the analysis of Alfred W. McCoy (1989: 120), Quezon became "the first Filipino politician with the power to integrate all levels of politics into a single system," as he directly manipulated provincial politics in order to challenge other national politicians' control over local vote banks; "Quezon once confessed to an aide that '90 percent' of his dealings with politicians involved the disposition of patronage."

The vote banks of the 1930s were considerably larger than those of the early American colonial period. As the result of various reforms, the number of registered voters had risen steadily from 105,000 in 1907 (a mere 1.2 percent of the population) to 1.6 million in 1935. After the 1937 enfranchisement of women, the proportion of the total population voting in congressional elections for the first time exceeded 10 percent; by 1940 , some 2.27 million Filipinos, or 14 percent of the total population, were registered to vote. ${ }^{13}$ The expansion of the electorate, however, did not present any major challenge to those who had been put in control of the Philippine political system in earlier decades. In the Taft era, it will be recalled, those at the bottom were unable to vote (or to express their political views in other ways), whereas those at the top were provided with ever-expanding opportunities to enjoy political power. These opportunities came first in municipalities, then moved to the provincial level, proceeded to a new national assembly, and eventually reached the national executive (briefly tasted in the Council of State and thoroughly savored by Quezon in the commonwealth twenty years later). Although theorists of democracy describe landowners as the social class likely to pose the biggest threat to the emergence of democracy, the American Philippines once again emerges as a striking exception to the rule. ${ }^{14}$ Because colonial rulers built a "democratic" system almost entirely for the benefit of the landlord class they were trying to woo away from the revolutionary struggle, these landlords learned to love the "democracy" they could so readily control. By the time the electorate had been expanded to include nonelites, the dominance of the newly created national oligarchy was so well entrenched that challenges from below-motivated by deep social injusticesfaced monumental odds.

Such challenges became increasingly apparent in the late American colonial period. Drawing on a long tradition of Spanish-era millenarian 
movements as well as widespread and enduring early-twentieth-century resistance to American rule, utopian nationalist movements emerged in the 1920s in the rice granary of central Luzon. "Victimized by land-grabbers, moneylenders, and landlords, and excluded from effective participation in the political process," writes Frank Golay, "peasant smallholders and tenants were driven to direct action to right the wrongs they faced." The 1930s brought more sustained political mobilization against landlords in protest against deteriorating conditions of tenancy. The Sakdal Party won considerable support in the 1934 legislative elections as it attacked the Nacionalistas for failing to demand early independence. After Quezon marginalized them through a variety of means, the Sakdalistas mounted an insurrection in major towns throughout central Luzon that the constabulary swiftly crushed "with unprecedented loss of dissident lives." Quezon also managed to contain the threats, for the time being, through calls for patience and tolerance and his 1937 proclamation of a sham "social justice" policy. ${ }^{15}$

Despite many changes in the structure of the political system from 1900 to 1941 , one can note many enduring legacies of the political institutions established by the United States in the Philippines. Our analysis of Taft-era colonial democracy has highlighted not only the systematic exclusion of the masses and the emergence of elite-controlled democratic institutions but also the provincial basis of national politics, the decline of ideological differences within the elite, and the emergence of a patronage-oriented party that was to become the prototype for most subsequent twentieth-century political parties. The Quezon era continued all of these legacies and added new legacies of its own: the potential for authoritarian centralization of political patronage in the hands of a strong executive. Although it is indeed true that the Philippines is the Asian country with the most enduring experience with democratic institutions, one must also conclude that its democracy got off to a decidedly inauspicious start.

During the Japanese occupation, the pretenses of democracy became more shallow than ever. While Quezon and Osmeña headed up the government-in-exile in Washington, the Japanese abolished all political parties and established in their stead Kalibapi, a so-called mass party that was in fact led by "a charter member of the Nacionalista oligarchy," Congressman Benigno Aquino Sr. (Steinberg 1967: 61-62, 64, 184). The most important new political formation, however, was the 1942 creation of the Hukbalahap (People's Anti-Japanese Army) to do battle against both the Japanese and their landlord collaborators. In response, there was a mass exodus of elites from the countryside to the 
relative safety of the cities (Kerkvliet 1977: 96). Wartime tensions between the Huks and U.S.-backed guerrilla forces worsened after General Douglas MacArthur's landing in October 1944, and the Huks (despite their frequent willingness to cooperate with U.S. forces) soon found themselves enemies of the state being reestablished by MacArthur and his many oligarchic friends (some of whom had collaborated with the Japanese during the war).

\section{Postindependence Political Parties, 1946-1986: Elite Hegemony, Mass Electorate, and Authoritarianism}

The war, and the countless intra-elite disputes that it engendered, destroyed the Nacionalista monopoly on political power. For the first time since the early years of the century, major cleavages emerged within an elite that was once again divided over how to relate to a new occupying power. Not surprisingly, one of the most important issues in postwar politics related to the major divisions between those who had collaborated with the Japanese and those who had not. Osmeña had assumed the presidency after Quezon's death in exile, but upon returning to the country he was soon challenged by a major rival from the old Nacionalista leadership. After being declared by MacArthur to be "free of wartime guilt," Manuel Roxas proceeded to form a new political party, the Liberals, and defeat Osmeña in the April 1946 elections (Steinberg 2000: 104-105).

The other major issue of early postwar democracy was mass challenges to elite hegemony. After the war, many on the left turned to parliamentary struggle and managed in the 1946 elections to have six members of its Democratic Alliance elected to the House of Representatives. In order to ensure the passage of a law granting parity rights for U.S. business, the Democratic Alliance representatives were barred from taking their seats. Meanwhile, repression of the peasantry grew worse in the countryside, and by late 1946 the Huk units were once again in full-scale rebellion (Shalom 1986: 1-69; Kerkvliet 1977: 143-202). The Huk Rebellion peaked between 1949 and 1951, after which counterinsurgency efforts began to achieve considerable success. Especially important was the role of U.S. advisers in cultivating Ramon Magsaysay, “America's boy” (Shalom 1986: 86-93). The major reason for the Huk decline, explains Benedict Kerkvliet, was that "peasants in Central Luzon liked Magsaysay, first as secretary of defense (1950-1953) and then as president (1954-1957), because he 
had personal contact with villagers and because the military became less abusive under his leadership" (Kerkvliet 1977: 238). Agrarian discontent was temporarily ameliorated through resettlement in Mindanao, and U.S. proposals for land redistribution were blocked; with the root causes of insurgency unaddressed, the left would eventually rise again (Shalom 1986: 84-85; Steinberg 2000: 26).

Throughout the period 1946-1972 (since known as the period of pre-martial law democracy), the Liberals and Nacionalistas alternated in power under the rules formally established by the 1935 constitution. Within a few years after the conclusion of the Pacific War, issues of Japanese collaboration had been eclipsed by other concerns, notably challenges from below and the never-ending struggles among political factions to secure their hold on the patronage resources of the state. Among the most important changes in the character of Philippine democracy resulted from an enormous increase in the size of the electorate. This was encouraged by the formal dropping of the literacy requirement (Rood 2002: 150) and far exceeded the substantial commonwealth-era growth rates already noted above. By 1951, the number of registered voters stood at 4.7 million (more than double that of 1940); this increased to 7.8 million voters in 1959 and 10.3 million voters in 1969 (Banlaoi and Carlos 1996).

Unlike in earlier years, therefore, political elites now had to convince nonelites to vote for them. At first, patron-client ties and deeply embedded traditions of social deference were sufficient. The organizational requirements of electoral campaigning remained relatively simple, as elites built factional coalitions in ascending order of complexity from the municipal level upward to the provincial and national levels. As Landé explains, local elite (often landholding) patrons used a variety of means-kinship, personal ties, and the offering of jobs, services, and other favors - to build a clientele composed of those from lower social classes. This clientele constituted a large vote bank, which could be exchanged for money and power from national politicians:

Strong local roots and an ability to survive independently give the factions considerable bargaining power in their dealings with the national parties. ... Candidates for national offices need votes, which local leaders with their primary hold upon the loyalty of the rural electorate can deliver. Local leaders in turn need money to do favors for their followers, and this the candidates for high offices can supply [e.g.,] ... public works projects and ... influence with the agencies of the central government. ... The result is a functional interdependence of local, provincial, and national leaders which promotes a 
close articulation of each level of party organization with those above and below it. (Landé 1965: 24, 82)

The "close articulation" of different levels of the party varied at different points of the four-year electoral cycle. Most presidents elected since independence in 1946 did not initially have working party majorities. In a few months, however, enough members of the majority party shifted to the president's party in order to get in line for patronage and pork. By the middle of the president's term, the number of officials expecting patronage shares became so large that it was impossible to make everyone happy. Toward the end of the president's term, the unhappy politicians outnumbered happy ones, making it difficult for the president to get reelected. As Landé concludes, "The balance of power between higher and lower levels of party organization is an unstable one" (Landé 1965: 82; Thompson 1995: 15). This strange political system, neither centralized nor decentralized, links powerful presidents and powerful local bosses in a relationship that is both symbiotic and highly variable (depending on the stage of the political cycle). The effect of this system is illustrated in the fate of elected administrations that could not afford to alienate the local clans that controlled political factions (and often private armies) in the countryside.

In addition to being "loose federations ... among independent factional leaders in the provinces," the two rival parties were also indistinguishable on ideological grounds (Landé 1965: 24). Not surprisingly, party-switching (known in the Philippines as "turncoatism") was rampant. One might expect that the relatively greater complexity of an economy formerly based almost entirely on agriculture would engender substantial new cleavages in a Philippine elite that had exhibited few substantial ideological divides throughout the century (with the exception, as noted above, of its responses to American and then Japanese conquest). Even with the diversification of the elite from agricultural into industrial and other ventures in the 1950s and 1960s, however, one can still not discern any sustained emergence of coherent cleavages within that elite. Beginning in the 1950s but becoming more obvious in the 1960s, there was instead a simultaneous process of diversification and homogenization: because it was so common for family conglomerates to combine ventures in agriculture, import substitution, banking, commerce, and urban real estate under one roof, major families continued to share a basic homogeneity of interests on major issues of economic policy. As in prewar years, there has been 
substantial consensus on big issues, and political battles were fought more exclusively over factional and personal issues that arise in the quest for the booty of state. One dominant segment of capital emerged and remains hegemonic to the present: the diversified conglomerates of oligarchic families (Hutchcroft 1998: 82-84).

The next stage in the development of political parties was set by the candidacy of Ramon Magsaysay in the presidential elections of 1953 , briefly noted above. His major innovation was to supplement the traditional reliance on patron-client ties with direct campaign appeals to the people. ${ }^{16}$ With the help of the U.S. Central Intelligence Agency, the popular former defense secretary formed the Magsaysay for President Movement and traveled extensively throughout the country. Political parties were effected not only by this new campaign style but also by the tendency of elite families to move beyond their simple prewar municipal party organization toward the construction of political machines "devoted primarily to the political support of its leader and the maintenance of its members through the distribution of immediate, concrete, and individual rewards to them." As municipal leaders built machines, there "was an increase in the importance of provincial and national considerations and a decline in the importance of local considerations in shaping the faction's character and its actions in all arenas" (Machado 1974: 525).

The continuing rapid growth of the electorate, combined with urbanization and the expansion of radio and television in the 1960s, amplified the impact of changes brought about by Magsaysay's direct appeals and the rise of more complex political machines. National campaigns now had to be organized on the basis of the segmentation of the vote into what can be called the "controlled vote" mobilized by local party leaders and that portion of the vote freer of such control and requiring increasingly elaborate media-oriented campaigns. The vastly increased financial requirements of national campaigns strengthened the national leadership vis-à-vis local party leaders, particularly to the extent that funds generated from the center (especially Manila) came to rival funds generated from the local economy (deriving in part from control over such activities as gambling, smuggling, and illegal logging). While local politicians still derived great power from their influence over the voters in their bailiwicks, they were somewhat less autonomous compared to earlier years. In the midst of change, it must be emphasized, there was also continuity: the growing electorate, the use of media, and mass campaigns forced an elaboration of political party organization, but there was no corresponding differentiation 
between political parties. The logic of patronage remained central to understanding the strategies of both the parties and the politicians.

The framework most commonly used to understand pre-martial law Philippine politics derives from Landé's work on factional networks and patron-client ties. In at least two major ways, however, this framework fails to capture important elements of political reality. Mark Thompson highlights the occasionally strong role of anticorruption and anti-electoral fraud movements in Philippine politics. Historically, there have been vocal, often middle-class elements of the Philippine electorate whose political participation is not primarily propelled by concrete material favors or stifled by cacique dominance but rather invigorated by outrage over authoritarian tendencies, corruption, and electoral abuses. As he explains, such appeals are closely related to antimachine urban reformism in U.S. politics and were at the center of Ramon Magsaysay's campaign in 1953 (as well as Corazon Aquino's campaign against Ferdinand Marcos in 1986; see below). ${ }^{17}$ Second, as the work of John Sidel convincingly argues, the patron-client framework also fails to give adequate attention to the role of violence and local monopolies in both Philippine electoral politics and social relations (i.e., the guns and the goons in the old troika of "guns, gold, and goons"). Throughout the archipelago, local bosses have enjoyed (and continue to enjoy) "monopolistic personal control over coercive and economic resources in their territorial jurisdictions and bailiwicks" (Sidel 1999).

The elite dominance that Benedict Anderson describes as "cacique democracy" had its "full heyday" in the period 1954-1972, when "the oligarchy faced no serious domestic challenges." Its genius, he writes, was its capacity to "[disperse] power horizontally, while concentrating it vertically." This horizontal dispersal of power, he continues, was able to "[draw] a partial veil over" the vertical concentration of power (Anderson 1988: 16, 33). Put somewhat differently, Philippine-style democracy provides a convenient system by which power can be rotated at the top without effective participation of those below. Because of the very substantial power of the president, explains Thompson, "a crucial but fragile rule of the political game was presidential succession" (Thompson 1995: 19, 23-24).

Ferdinand Marcos, elected president in 1965 , steadily pushed the limits of this rule until he broke it entirely in 1972. Unlike his predecessors, who busted the budget only in election years, Marcos "ran deficits even in off years to fund a massive infrastructure program that was parceled out for maximum political advantage" (Thompson 1995: 
34-35). He augmented the already enormous budgetary powers of the Philippine presidency with new discretionary funds that could be distributed directly to officials at the barrio level for "community projects." As Arthur Alan Shantz (1972: 148) explains, the Marcos administration "sought to broaden the flow of resources and executive contacts beneath the congressmen and into the municipalities, minimizing its dependence upon the political brokers in the legislative branch who have historically proven to be such a disappointment to incumbent presidents seeking reelection." Marcos also used the military in development projects and sent an engineering battalion to Vietnam in exchange for large, off-the-books payments from Washington (Hernandez 1984: 18-19; Bonner 1987: 75). Marcos became the first president to win reelection when, in 1969, he raided the public treasury and thereby hastened the arrival of the country's third major balanceof-payments crisis. As his defeated opponent grumbled, "[We were] out-gooned, out-gunned, and out-gold."

Determined to overturn the two-term limit prescribed by the 1935 constitution, Marcos declared martial law in 1972. As Benedict Anderson explains,

From one point of view, Don Ferdinand can be seen as the Master Cacique or Master Warlord, in that he pushed the destructive logic of the old order to its natural conclusion. In place of dozens of privatized "security guards," a single privatized National Constabulary; in place of personal armies, a personal Army; instead of pliable local judges, a client Supreme Court; instead of myriad pocket and rotten boroughs, a pocket or rotten country, managed by cronies, hitmen, and flunkies. (Anderson 1988: 20)

As Congress was disbanded and the judiciary cowed into submission, the United States rewarded martial law with very large increases in grants and loans (in exchange for unimpeded use of its military bases) (Wurfel 1988: 191). The absence of elections, combined with Marcos's monopoly of political power, left pre-martial law political parties severely weakened. Marcos had no allegiance to the Nacionalista Party (on whose ticket he won the presidency in 1965 after a lastminute switch from the Liberal Party); neither did he show any inclination for creating a new type of highly institutionalized party such as those found nearby in authoritarian Indonesia and Taiwan. It was not until 1978, in preparation for elections to the long-promised Interim National Assembly, that the Marcos regime launched its own ruling party, the Kilusang Bagong Lipunan (KBL; New Society Movement). 
The rhetoric of a "new society" notwithstanding, the old, informal patronage politics of the pre-martial law years remained the fundamental basis of the KBL.

In at least three major ways, however, the emergence of the KBL represented a major break from pre-martial law patterns. First, to a far greater extent than any Philippine president since Manuel Quezon and his Nacionalista Party in the 1930s, Marcos and his KBL achieved a masterful centralization of patronage resources (McCoy 1989). Throughout much of the country, politicians flocked to the KBL for the benefits that it could dispense. Local officials, who could be replaced at will by the regime, were particularly anxious to join the ruling party. The earlier "close articulation" of national, provincial, and local politics endured, but the balance of power came to be tilted much more decisively in favor of the national. Significantly, however, even Marcos could not attempt a full-scale assault on local power; he was able to restructure but not undermine the influence of clan-based factions in the provinces (McCoy 1993). Second, to a degree unprecedented in Philippine history, the ruling family lorded over all formal political institutions, the ruling party included. Third, there was considerable overlap between the structures of the ruling party and the crony abuses that defined the essential character of the Marcos regime.

The electoral exercises of the latter Marcos years did bring forth new elite-led political parties seeking to challenge the KBL in elections, but by the late 1970s and early 1980s the major challenge to the regime came from an entirely new type of ideologically driven party: the Communist Party of the Philippines (CPP). Throughout the 1960s, Philippine students had become increasingly politicized and radicalized, provoked by campus issues, the presence of U.S. bases, the U.S. war in Vietnam and the deployment of Philippine troops there, inequitable social structures and the need for agrarian reform, and electoral fraud and demands for constitutional reform. The CPP was officially launched in late 1968, but it was not until after the declaration of martial law that it was able to build strong bases of support throughout many regions of the archipelago. Its New People's Army came to be the hope of many Filipinos across different social strata who desperately sought the demise of the Marcos dictatorship; the traditional politicians, by comparison, looked liked impotent has-beens.

With the assassination of Benigno Aquino Jr. in 1983, the traditional elite increasingly abandoned Marcos and organized effective opposition efforts under the mantle of his popular widow, Corazon Cojuangco Aquino. Although these elites still lacked access to patron- 
age, it was possible for them to build support based on opposition to rampant cronyism, human rights abuses, and economic decline. In the wake of the February 1986 "snap elections," anger over the regime's blatant electoral fraud and other abuses of the political system brought hundreds of thousands of people out into the streets in a huge display ("People Power") to defend a military uprising and support Aquino. The CPP, having chosen to boycott the elections, found itself on the sidelines. As Marcos and his family fled the palace for Hawaii, it was Aquino - a member of a very prominent oligarchic family-who was sworn into office at an elite club in Manila.

\section{Philippine Democracy After 1986: Restoration and Change}

Cory Aquino's rise to power needs to be seen in the context of both the antidictatorship and social justice demands of the opposition to her predecessor, Ferdinand Marcos. Once in power, however, Aquino saw her primary duty as restoring the structures of pre-martial law democracy. To call this period a mere "restoration" of pre-martial law democracy, however, only goes so far, given: (1) the degree to which Philippine civil society was far more active and organized after 1986 than it had been prior to 1972; and (2) the degree to which the Philippine military had become a much more politicized force over the course of the martial-law years.

The Philippines, of course, had changed a lot during the twentyone years that Marcos was in power. Aquino herself discovered this in her difficult relations with two new centers of power: the military and civil society. Disgruntled elements of the military launched a total of nine coup attempts against Aquino and, in two cases, came close to toppling her from office (McCoy 1999: 259). Philippine nongovernmental organizations (NGOs) began to mushroom in the 1980s, as thousands of groups formed to promote the interests of farmers, the urban poor, women, and indigenous peoples (Silliman and Noble 1998). Despite these major changes, the political system that Aquino reconstructed with the 1987 constitution restored many political institutions that can be traced to the 1935 constitution, most importantly a presidential form of government that went back to the political system built by the American colonial authorities and Filipino leaders. Aquino's difficulties, therefore, were not just those of moving from a dictatorship to constitutional democracy. They also arose because the political system she 
put in place continued to discourage the emergence of stronger, more programmatic political parties-and thus did not give room for the assertion of new political groups' ideas and interests.

The 1987 constitution reads like a completely different constitution from that of 1935. Many of the new ideas generated in the course of the antidictatorship movement found their way into the 1987 constitution. Among the institutional innovations were sectoral representation in local government councils and party-list elections for 20 percent of the members of the lower house (the remaining 80 percent of which were to remain under the single-member district plurality system of pre-martial law democracy). As with many other progressive provisions in the 1987 constitution, however, implementing legislation was either not passed (as in the case of sectoral representation) or mangled beyond recognition (as in the case of the party list) (see Velasco and Rodriguez 1998). The effective reinstatement of pre-martial law electoral and representational structures facilitated the restoration of the power of local clans, who through a variety of means have prevented significant political reform since $1986 .^{18}$ The so-called traditional politician, seen as the source of many national ills, became popularly known as trapo (meaning "dishrag" in Tagalog).

The old parties did not survive, and the new parties that did emerge remained remarkably similar in their orientation toward patronage, reliance on coalitions of local elites, nonideological character, and shifting membership. Given its poorly institutionalized character, the KBL did not survive the demise of its authoritarian leader, and neither the Nacionalista Party nor the Liberal Party recovered their former stature. Most dramatic is the shift from a two-party to a multiparty system. Because single-member district plurality systems are expected to yield a two-party system, the question arises as to why post-1986 Philippine politics has produced so many weak and unstable parties. Jungog Choi (2001: 499) concludes that the provision of the 1987 constitution limiting presidents to a single term increases the number of candidates "because none of the individuals running has the incumbency advantage. Such a limitation significantly lowers the entry barrier for prospective candidates." (Not surprisingly, given the weakness of Philippine parties, it is the number of candidates that determines the number of political parties, not vice-versa.) While this is a compelling argument, other factors are also important to consider (see Bevis 2001: 13, 28-29). Given the thoroughly unsystematic character of Philippine political parties, moreover, there are fundamental problems with the use of the term "multi-party system." 
Because of the pressures Aquino faced from the military, and because her main goal appears to have been mostly to restore the system for mediating elite factional competition, she missed several other historic opportunities for both economic and political reform that were possible in 1986-1987, including more radical agrarian reform and the negotiated repudiation of the more obviously corrupted international loans. The most innovative political reform during the Aquino years was the Local Government Code (LGC) of 1991, a decentralization initiative that has the capacity in many localities to encourage greater local democratic participation-and carries the danger in other places of entrenching local authoritarian enclaves. ${ }^{19}$ For current purposes, the most important question is the extent to which the LGC may hold promise for altering the character of Philippine political parties. By providing local politicians with automatic and greatly increased allotments of resources from the central government, ${ }^{20}$ the terms of exchange are altered: local officials have relatively less need to beg for patronage resources from Manila, yet national-level politicians continue to need their help in delivering the votes from the provinces.

In addition to the provisions of the LGC, economic growth and diversification provide alternative resources to local executives who had long relied on some combination of funds from Manila as well as control over illegal economic activity at home. Overall, this has the effect of shifting the balance of power and patronage toward local politicians (especially the mayors who benefited most from the revenue transfers instituted by the LGC), as well as encouraging the further decentralization of political parties that were never strongly centralized in the first place. At the same time, many feel that the LGC holds great promise in helping to undermine the basic logic of patronage that has governed Philippine politics for so long. In an optimal scenario, the LGC encourages new types of popular participation and new types of political leadership at the local level, which in turn can engender new pressures for important political reforms at the national level.

Fidel Ramos came to power in 1992 with a much stronger reform impulse, but his reform initiatives were concentrated far more in the economic than the political realm. Ramos and his chief theoretician, former general Jose Almonte, blamed oligarchic groups for the country's laggard economic status and combined measures of economic liberalization, privatization, and infrastructure development with concerted attacks on "cartels and monopolies." At the same time, they asserted the need to build a more capable state and free the state of oligarchic influence. Ramos seemed better placed to do this than other 
politicians because, as former chief of staff of the armed forces, he had strong institutional backing from the military and could not be accused of being a traditional politician. Many in the business community, intelligentsia, and middle classes sympathized with the call for a stronger, more effective state.

The Ramos administration was proud to demonstrate the compatibility of development and democracy, but it consistently had to rely on old-style pork-barrel politics in order to promote new-style economics (Rocamora 1995). Little was done to try to improve the quality or substance of Philippine democracy. Without strong parties, policymaking was dominated by a process of deal-making that made it difficult to pass coherent bills (much less a series of interrelated legislation). Unfortunately for Ramos, his one major attempt at political reform was poorly managed. A conspicuously authoritarian draft revised constitution formulated by a team at the National Security Council was exposed by the media. By the time the charter change (immediately dubbed "Cha-Cha") campaign got going again, it was too close to the elections to effectively hide its term-limit extension goals.

Estrada rode to overwhelming victory in 1998 with strong populist rhetoric and the enthusiastic support of millions of poor Filipinos, many of whom felt that Ramos had ignored their interests. It was, in the words of one Philippine political analyst, "the revenge of the masses. They are tired of being led by smart people." The victory of Estrada was part of a continuing post-1986 political trend for the electorate to reject the discredited traditional politician, or at least its stereotype. "Though possessing a long political career as a local official," explains Emmanuel de Dios, "the ex-actor Estrada's rise to prominence had bypassed the customary route of obvious patronage and horse-trading that typified the traditional politician's career at the national level, relying instead on media-driven national name-recognition" (de Dios and Hutchcroft 2002). In essence, one can note the emergence of a new kind of patronage politics, as Estrada's media-generated populist appeals coexisted quite readily with much older styles of exchange between national politicians and local clan-based political machines.

As the politics of personality were expressed in new ways, party structures seem to have become even weaker and more marginal to the overall political process: throughout his term, Estrada relied on loose and ill-defined coalitions and did not even bother to build up his own political party. Redistributive rhetoric was expressed, concretely, through an antipoverty program that never took off and easily degenerated into a grab for patronage among local officials and privileged 
NGOs (Balisacan 2001). And the bulk of the redistributive effort, of course, benefited not the masses but Estrada's myriad cronies and multiple families. The poor would have been best served by the emergence of strong political parties able to give them a voice in a political environment long hostile to their interests; what they got instead, sadly, was a corrupt populist claiming to help the poor while he made himself rich.

To summarize, post-Marcos hopes for a new system of politics have been largely undermined by the restoration of much the same institutional structure as that found in pre-martial law politics. One can note three different styles of presidential leadership: Corazon Aquino as elite restorationist, with little goal other than the rebuilding of democratic institutions undermined by her authoritarian predecessor; Fidel Ramos as military reformer, concentrating more on issues of economic than political reform; and Joseph Estrada as populist self-aggrandizer, building a strong following among the masses and then redistributing wealth in favor of himself, his families, and his friends. Despite these differences in leadership, the logic of patronage remains central to understanding Philippine politics, and political parties remain weak, illdefined, and poorly institutionalized. Changes in the social structure might be seen as an impetus for major changes in the character of politics: one finds not only a younger, more urbanized population less tied to old patron-client structures but also the emergence of thousands of new NGOs and a much more politically active civil society. The fundamental constraint, however, continues to lie with the character of political institutions, the failure of which became more apparent than ever in the January 2001 fall of the populist Estrada through popular uprising and his replacement by Gloria Arroyo-Macapagal.

\section{The Current Crisis of Philippine Democracy}

Vice President Arroyo became president in January 2001 when People Power 2, a huge four-day mass action, persuaded the military to withdraw support from the Estrada government. Joseph Estrada quickly lost the support of key sectors of the elite and the middle classes when he brazenly siphoned off billions of pesos of public money to his private bank accounts. Estrada was brought down by a coalition of civil society groups, segments of big business, media, and the Catholic Church, and reformers within the military and civilian bureaucracy. While generally considered beneficial to the future of democracy, People Power 2 also showed the rigidity of the presidential system and the difficulty 
of unseating an elected president through constitutional means. The election of Estrada itself, one accomplished without significant political party support, showed the vulnerability of the electoral system to populist appeals.

Estrada's cupidity seriously damaged key institutions, including the police and the stock market and, of course, the presidency. An attempt to remove him through a constitutionally mandated impeachment process failed not because he was acquitted but because his supporters in the Senate blocked the process. One could argue therefore that People Power 2 "unblocked" the constitutional process. In addition, removing Estrada halted the attacks on key institutions and reopened the political and economic reform process. Taken together, these results contributed to advancing the democratization process in the Philippines.

The supreme court affirmed the legality of Arroyo's assumption of the presidency in several decisions. But as a method for removing an elected president, People Power 2 was, without doubt, extraconstitutional. As a result, the mandate and authority of the Arroyo administration leaves much to be desired. After taking office, President Arroyo was assailed by coup rumors and destabilization plots. She made matters worse by refusing to be firm in disciplining corrupt and incompetent military officers.

The urban poor's rage that burst forth in subsequent months brought home the dangers inherent in a political system incapable of stemming the continued widening of the gap between the many poor and few rich. Beginning in late April up to May Day 2001, the violent reaction to Estrada's arrest (in late April) dramatically revealed a huge chasm in Philippine society. A prolonged rally by his supporters ended in a bloody, riotous attack on the presidential palace on May 1. Former president Estrada sits in jail, albeit a well-appointed one in a hospital. Using a combination of legal challenges, destabilization, and coup rumors, Estrada and his allies challenge the Arroyo government to make a choice between old-style intra-elite accommodation and pursuing Estrada's trial and asserting the "rule of law." Beyond Estrada's culpability for the crime of plunder, his political maneuvers to avoid conviction illustrate the vulnerability of the political system to populist politics. "From the perspective of his poor supporters," explains Cynthia Banzon Bautista (2002: 33),

Estrada's rise and fall from the presidency are conflated with their own long-standing struggle to lift themselves from poverty. Tradi- 
tional politicians and Estrada himself used this view and the very real class divide to obfuscate the issues. They peddled his prosecution as an attack on the poor rather than on the very system of "old politics" that Estrada represents and which has, in large part, prevented the liberation of the poor.

Within months of coming to power, President Arroyo faced a national election in May 2001. The government's electoral vehicle, the People Power Coalition (PPC), seemed to carry the reform sentiments of People Power 2. In practice, PPC ran a traditional campaign in what was arguably the most fraud-ridden election in decades. Because neither the PPC nor the parties within it had significant mobilization capacity as parties, campaigning was mainly a matter of negotiating with local politicians who had vote-generation capability. After the election, PPC ceased to exist. President Arroyo has done nothing about the political system's main weakness, the absence of real political parties, and, at least nominally, belongs to three different parties.

In her first two years in office, while consolidating her hold on the presidency, Arroyo relied primarily on old styles of elite politics as she paid off a host of debts to those who had made possible her assumption of high office. Toward the end of 2002, she was said to have become increasingly concerned about declining support among reformist groups and the urban middle to upper classes. After she surprised the country with a December 30 announcement that she would not run for reelection in 2004 and concentrate instead on economic reforms, President Arroyo began to regain popular support. By mid-January, she voiced support as well for the growing movement to call a constitutional convention in 2004. Unlike her predecessors, she can now push for important political reforms without being unduly burdened by charges that she is doing so for her own selfish purposes.

In the Ramos and Estrada administrations, constitutional reform was hijacked by sitting presidents for transparently selfish purposes. As a result, reform forces in civil society, business, and the churches mobilized against constitutional reform in 1997, then again in 1999. This time around, these forces are mobilizing for constitutional reform, not against. Although major differences of details remain as to the means and goals of constitutional revision, the broad concept of "Cha-Cha" has been backed by the Speaker of the House, the President of the Senate, other influential opinion-makers, and now the president herself (on the dynamics of these recent developments, see Rocamora 2003a and $2003 \mathrm{~b}$ ). As of early 2003, it seems that momentum is building to hold 
elections for a constitutional convention in May 2004 (to be held simultaneously with already scheduled presidential and congressional elections).

\section{New Century, New Imperatives}

In this article, we have demonstrated how many of the major characteristics of Philippine democracy can be traced to the institutional innovations of the American colonial era: the exclusion of the masses and elite hegemony over democratic institutions; the provincial basis of national politics; the overarching dominance of patronage over ideology as the primary foundation of Philippine political parties; and a powerful presidency. These basic characteristics have endured amid enormous transformations in Philippine politics, including the rise and defeat of armed challenges to elite domination at midcentury, independence in 1946, the creation of a mass electorate, the long nightmare of martial law, the reemergence of armed opposition in the countryside during the Marcos dictatorship, the toppling of Marcos via broad-based "people power" in 1986, the growth of a vigorous NGO sector, the economic reforms of the 1990s, the populism of Joseph Estrada, and the resurgent People Power uprising that forced Estrada from office in 2001.

Through the current crisis, it has become clear-or at least it should be clear-that Philippine democracy can no longer ignore the interests and demands and resentment and anger of those at the bottom of society. For those inclined to downplay the extraordinary large class divides in Philippine politics, the popular uprising of May 2001 should serve as a high-decibel, cacophonous, and obtrusive wake-up call. While theorists explain that "democracy is a rather counterintuitive state of affairs, one in which the disadvantaged many have, as citizens, a real voice in the collective decision making of politics," Philippine democracy has done strikingly little to give the disadvantaged a voice. And while theorists further assert that "democracy takes on a realistic character only if it is based on significant changes in the overall distribution of power," Philippine democracy fails to give any substantive challenge to highly inequitable socio-economic structures (Rueschemeyer, Stephens, and Stephens 1992: 41).

Because the institutional innovations of the early twentieth century bear much of the blame for the many shortcomings of Philippine democracy, the beginning of a new century is a particularly appropriate time to 
reform democratic structures and build a political system able to offer benefits to all. Just as different institutional arrangements could have induced different patterns of state-society relations in the colonial era, current proposals for reform of representational and electoral structures hold out promise for vastly improved governance in the decades ahead. Parties and the electoral process remain dominated by personalities rather than programs; legislative institutions continue to be the domain of many of the same old political clans and trapos; and the legislative process is still driven by the politics of pork and patronage. A major challenge-the orderly attainment of which can only come through the long-term cultivation of stronger and more programmatic political parties -is to insulate structures from particularistic demands (especially from the dominant oligarchy) and open them up to respond more effectively to collective pressures from societal groups whose interests have long been marginalized. In short, the creation of stronger parties is the most important way of closing the democratic deficit and making Philippine democracy more responsive to the citizenry as a whole. The new century demands a new type of political party. As momentum builds toward a constitutional convention in 2004, its number-one priority should be a new set of institutional innovations, in representational and electoral structures, that will work toward this goal above all others.

Paul D. Hutchcroft, associate professor of political science at the University of Wisconsin-Madison, is currently based in the Philippines on the Fulbright-Hays Faculty Research Abroad Program. Joel Rocamora is executive director of the Institute for Popular Democracy, in Quezon City, and president of Akbayan (Citizens Action Party).

\section{Notes}

The authors gratefully acknowledge the helpful comments of C. T. Kuo and other participants in the March 2002 Taipei conference on crises of democracy in Asia, Gladstone Cuarteros, Amado Mendoza Jr., and two anonymous readers. Particular thanks to Byung-Kook Kim for the many insights he has provided as we have revised this analysis. Any errors or omissions, of course, are ours alone.

1. A May-June 2002 survey conducted by the Social Weather Stations showed only 35 percent satisfaction with "the way democracy works" (Abueva 2002: 1-4). In the previous decade, the level of satisfaction was consistently above 40 percent and on two occasions (1992 and 1998) roughly 70 percent $(\operatorname{Rood} 2002$ : 149). 
2. As Gabriella Montinola (1999: 133) explains, "Meaningful social change has been inhibited because political parties have failed to structure political competition to allow for the representation of interests of the poor and marginalized sectors. ... Quality of choice depends on political parties, the main organizations that structure political competition."

3. The analysis of this article, we should explain at the outset, is more diagnostic than prescriptive. There is currently much discussion in the Philippines about constitutional revision but surprisingly little analysis as to what the end goal (or goals) of reform should be. Through this examination of the origins and evolution of the country's "democratic deficit," we argue that the foremost goal of political reform should be the building of stronger parties. We do not provide comprehensive analysis of (1) the specific structural reforms by which this should be accomplished, or (2) the political dynamics of the process through which change of representational and electoral structures might be instituted. These are extremely important issues but, unfortunately, are beyond the scope of this brief analysis.

4. The eminent Filipino political scientist Jose Abueva makes a distinction between "faith in democracy as an ideal" and "the way democracy works." A November 2001 survey, Abueva points out, showed a high 72 percent agreeing with the statement "democracy is the best political system in all circumstances" (Abueva 2002: 1-4). This faith in democracy is further evidenced by historically high turnouts in elections, despite the fact that voting is not compulsory. In the 1998 elections (for presidential, legislative, provincial, and municipal posts), there was 86 percent voter turnout (Rood 2002: 148, 150).

5 . We are not arguing, however, that democratic reform and the creation of stronger parties will resolve all problems of governance in the Philippines. Rather, these reforms are of a "necessary but not sufficient" character and must be supplemented by sustained attention to other elements of governance as well. First, the effective delivery of public goods also requires major improvements in the quality of the Philippine bureaucracy, at both the national and the local levels. Second, we are not ignoring the importance of wise policy choices once stronger democratic and administrative institutions have actually been put in place.

6. The following draws on Hutchcroft (2000).

7. The contrast with the Japanese conquest of Korea makes this point most clearly. There, the institutional innovations of the colonial power transformed a political-economic elite into a mere economic elite. The major foundation of this economic elite—landholding — did not translate into any significant degree of political power; in fact, the Japanese very much excluded Korean landholders from any substantial role in politics (see Hutchcroft 2002). Had the Japanese instead of the Americans become the colonial rulers of the Philippines in 1900 , one might speculate, Japanese institutional reforms would have created a very different type of Philippine elite.

8. Under the Spanish, provincial governors (exclusively Spaniards) were centrally appointed, with elections allowed only at the municipal level. The revolutionary Malolos republic, established in 1898, had a more extensive sys- 
tem of elected municipal and provincial officials, but its influence was shortlived.

9. In his second major category, "externally mobilized" parties are established by those outside the regime who do not have access to patronage and instead rely on ideological appeals in their quest for a mass following. Examples, he explains, are "socialist parties in Europe and nationalist parties in the Third World."

10. For further application of the Shefter framework to the Philippine political system, see Hutchcroft (2000: 282, 296, 298).

11. Golay (1998: 235-269, quote at 243). Hayden reports two points at which a two-party system began to emerge out of the Quezon-Osmeña rivalry: after their formal split in 1922, and again in the early 1930s when the two politicians feuded over the terms of the legislation establishing the commonwealth. "Upon each occasion, however, the transcendent issue of national independence was used to destroy the opposition as soon as it attained real strength" (Hayden 1942: 452).

12. In the legislative sphere, this includes what Bolongaita calls veto, initiating, summoning, and endorsement and delegated powers; in the executive sphere, great discretion over budgets, appointments of local government executives (and many others), and emergency powers (Bolongaita 1996: 99-100). Sergio Osmeña, Quezon's former rival, was elected vice president.

13. The 1935 constitution provided for literacy but not property requirements and lowered age limits from twenty-three to twenty-one (Hayden 1942: 825). Landé (1965: 28) notes that "growing laxity in the enforcement of literary requirements" and "the spread of literacy" expanded the size of the electorate in the early decades of the century, "in both absolute numbers and the percentage of the population that voted." The 1907 and 1935 data on absolute voters are from Banlaoi and Carlos (1996: 16, 17, 20, 34); 1907 and 1935 data on proportion of voters to total population from Salamanca (1984: 57; Landé 1965: 29); 1940 data from Hayden (1942: 204).

14. "The landed upper-classes which were dependent on a large supply of cheap labor were the most consistently anti-democratic force," write Rueschemeyer, Stephens, and Stephens (1992: 8, 60). "Any class that is dominant both economically and politically will not be eager to dilute its political power by democratization."

15. Ileto (1979); Kerkvliet (1977: 26-60); Golay (1998: 339-341, quotes at 339,341 ); see also Hayden (1942: 376-400). In 1940, moreover, the protenant Socialist Party registered strong gains in local elections in the province of Pampanga (Golay 1998: 400).

16. The long-term weakening of patron-client ties had been an important factor in the rise of the Huks during the Japanese occupation and the renewal of armed struggle after the war (Kerkvliet 1977: 249-252).

17. Thompson (1995: 29-32). Eva-Lotta Hedman (2001: 7) argues that strong movements for clean elections (in 1953, 1969, and 1986) can be seen as part of larger "cycles of protest" in which a "dominant bloc of social forces" 
not only protests authoritarian trends but also seeks to undermine extra-electoral challenges from below.

18. One leading study describes the first post-Marcos legislature as "the return of the oligarchs." Eighty-three percent of the House came from elite families, 66 percent had previously participated in elections, and 22 percent had been elected to Marcos's legislative body in 1984 (Gutierrez et al. 1992: 162). Similar trends persisted in subsequent legislatures. See Gutierrez (1994: $4)$.

19. On the political dynamics of the passage of the LGC, see Hutchcroft (2001).

20. In the five-year period before the passage of the LGC, only 11 percent of internal revenue collections were returned to local governments. The LGC increased this to 40 percent and made the local government internal revenue allotment automatic. Local government units were also given new taxing powers and the authority to incur debt. In those municipalities where economic activity had significantly enlarged the tax base, these changes often brought important changes in the architecture of local politics.

\section{References}

Abad, Florencio. 1997. "Should the Philippines Turn Parliamentary? The Challenge of Democratic Consolidation and Institutional Reform." In Soliman Santos, ed., Shift. Manila: Ateneo Center for Social Policy and Public Affairs.

Abueva, Jose. 2002. "Dissatisfaction with the Way Our Democracy Works." In Jose Abueva, ed., Towards a Federal Republic of the Philippines: A Reader. Manila: Center for Social Policy and Governance, 2002, pp. 1-4.

Alejo, Myrna, and Joel Rocamora. 2000. "Explaining Erap." Political Brief (February 2000): 16-27.

Anderson, Benedict. 1988. "Cacique Democracy and the Philippines: Origins and Dreams." New Left Review, no. 169: 3-33.

Balisacan, Arsenio M. 2001. "Did the Estrada Administration Benefit the Poor?" In Amando Doronila, ed., Between Fires: Fifteen Perspectives on the Estrada Crisis. Manila: Anvil.

Banlaoi, Rommel C., and Clarita Carlos. 1996. Elections in the Philippines: From the Pre-Colonial Period to the Present. Manila: Konrad Adenauer Foundation.

Banzon Bautista, Maria Cynthia Rose. 2002. "People Power 2: 'The Revenge of the Elite on the Masses'?" In Armando Doronila, ed., Between Fires: Fifteen Perspectives on the Estrada Crisis. Manila: Anvil.

Bevis, Gwendolyn G. 2001. "Party Time? The Formation of Programmatic Parties in the Philippines." Unpublished manuscript, Department of Political Science, University of Wisconsin-Madison. 
Bolongaita, Emiliano P. 1996. "The Breakdown of Philippine Democracy: A Comparative Institutional Analysis.” Ph.D. diss., Notre Dame University.

Bonner, Raymond. 1987. Waltzing with a Dictator: The Marcoses and the Making of American Policy. New York: Times Books.

Choi, Jungog. 2001. "Philippine Democracies Old and New: Elections, Term Limits, and Party Systems." Asian Survey 41, no. 3: 488-501.

Corpuz, Onofre D. 1957. The Bureaucracy in the Philippines. Manila: University of the Philippines Institute of Public Administration.

Cullinane, Michael. 1989. "Ilustrado Politics: The Response of the Filipino Educated Elite to American Colonial Rule, 1898-1907.” Ph.D. diss., University of Michigan.

- Forthcoming 2003. Ilustrado Politics: Filipino Elite Responses to American Rule, 1898-1908. Quezon City: Ateneo de Manila University Press.

David, Randolph. 2001. "Political Parties in the Philippines." In Randolph David, ed., Reflections on Sociology and Philippine Society. Manila: University of the Philippines Press, 2001, pp. 170-128.

de Dios, Emmanuel S., and Paul D. Hutchcroft. 2002/2003. "Philippine Political Economy: Examining Current Challenges in Historical Perspective." In Arsenio Balisacan and Hal Hill, eds., The Philippine Economy: Development, Policies, and Challenges. Quezon City: Ateneo de Manila University Press (2002); and New York: Oxford University Press (2003).

Golay, Frank. 1998. Face of Empire: United States-Philippine Relations, 1898-1946. Madison: University of Wisconsin Center for Southeast Asian Studies.

Gutierrez, Eric. 1994. The Ties That Bind: A Guide to Family, Business, and Other Interests in the Ninth House of Representatives. Metro Manila: Philippine Center for Investigative Journalism and Institute for Popular Democracy.

Gutierrez, Eric U., et al. 1992. All in the Family: A Study of Elites and Power Relations in the Philippines. Quezon City: Institute for Popular Democracy.

Hayden, Joseph Ralston. 1942. The Philippines: A Study in National Development. New York: Macmillan.

Hedman, Eva-Lotta E. 2001. "Cycles of Protest in Philippine Political and Civil Society: EDSA Dos in Comparative Historical Perspective." Presented to the Fourth European Philippine Studies Conference, Alcala de Henares, Spain.

Hernandez, Carolina G. 1984. "The Role of the Military in Contemporary Philippine Society." Diliman Review 32 (1) (January-February): 1, 16-24.

Hutchcroft, Paul D. 1998. Booty Capitalism: The Politics of Banking in the Philippines. Ithaca: Cornell University Press.

. 2000. "Colonial Masters, National Politicos, and Provincial Lords: Central Authority and Local Autonomy in the American Philippines, 1900-1913." Journal of Asian Studies 59, no. 2 (May): 277-306. 
2001. "State Formation, State Reformation: Deciphering Decentralization in the Philippines and Thailand." Unpublished manuscript.

. 2002. "Reflections on a Reverse Image: South Korea Under Park Chung Hee and the Philippines Under Ferdinand Marcos." Prepared for a collaborative research project on the Park Chung Hee era, organized by the East Asia Institute, Korea University, and the Asia Center, Harvard University.

Ileto, Reynaldo. 1979. Pasyon and Revolution: Popular Movements in the Philippines, 1840-1910. Quezon City: Ateneo de Manila University Press.

Kerkvliet, Benedict J. 1977. The Huk Rebellion: A Study of Peasant Revolt in the Philippines. Berkeley: University of California Press.

Kerkvliet, Benedict J., and Resil B. Mojares, ed. 1991. From Marcos to Aquino: Local Perspectives on Political Transition in the Philippines. Quezon City: Ateneo de Manila University Press.

Lacaba, Jose F., ed. 1995. Boss: 5 Case Studies of Local Politics in the Philippines. Metro Manila: Philippine Center for Investigative Journalism and Institute for Popular Democracy.

Landé, Carl H. 1965. Leaders, Factions, and Parties: The Structure of Philippine Politics. New Haven, CT: Yale University Southeast Asian Studies.

- 1969. "Brief History of Political Parties." In Jose Abueva and Raul De Guzman, eds., Foundations and Dynamics of Filipino Government and Politics. Manila: Bookmark.

Leones, Errol B., and Miel Moraleda. 1998. "Philippines." In Wolfgang Sachsenröder and Ulrike E. Frings, eds., Political Party Systems and Democratic Development in East and Southeast Asia, Volume I: Southeast Asia. Brookfield, VT: Ashgate.

Linz, Juan J. 1978. "Excursus on Presidential and Parliamentary Democracy." In Juan J. Linz and Alfred Stepan, eds., The Breakdown of Democratic Regimes. Baltimore: Johns Hopkins University Press.

Machado, K. G. 1974. "From Traditional Faction to Machine: Changing Patterns of Political Leadership and Organization in the Rural Philippines." Journal of Asian Studies 33, no. 4 (August): 523-547.

May, Glenn Anthony. 1984 [1980]. Social Engineering in the Philippines: The Aims, Execution, and Impact of American Colonial Policy, 1900-1913. Quezon City: New Day Publishers.

McCoy, Alfred W. 1989. "Quezon's Commonwealth: The Emergence of Philippine Authoritarianism." In Ruby R. Paredes, ed., Philippine Colonial Democracy. New Haven, CT: Yale University Southeast Asia Studies, Monograph No. 32.

- 1999. Closer Than Brothers: Manhood at the Philippine Military Academy. New Haven, CT: Yale University Press.

McCoy, Alfred W., ed. 1993. An Anarchy of Families: State and Family in the Philippines. Madison, WI: Center for Southeast Asian Studies.

Mijares, Primitivo. 1986 [1976]. The Conjugal Dictatorship of Ferdinand and Imelda Marcos I. San Francisco: Union Square Publications. 
Montinola, Gabriella R. 1999. "Parties and Accountability in the Philippines." Journal of Democracy 10: 126-140.

Paredes, Ruby R. 1989. "The Origins of National Politics: Taft and the Partido Federal.” In R. R. Paredes, ed., Philippine Colonial Democracy. New Haven, CT: Yale University Southeast Asia Studies.

Recto, Claro M. 1953 [1971]. "The Political Philosophy of Manuel L. Quezon." A speech delivered on the seventy-fifth birthday anniversary of President Quezon, August 19, 1953, reprinted as an appendix to Carlos Quirino, ed., Quezon: Paladin of Philippine Freedom, pp. 391-403. Manila: Filipiana Book Guild, 1971.

Rivera, Temario C. 2002. "Transition Pathways and Democratic Consolidation in the Post-Marcos Philippines." Paper presented at the annual meetings of the Philippine Political Science Association, Cebu City, November 8-9.

Rocamora, Joel. 1995. "The Political Requirements of Economic Reform," Issues and Letters 4 (October): 1-4.

_. 2003a. "How to Be Rizal Without Really Dying." Newsbreak 3, no. 2 (February 3): 35.

- 2003b. "The Constituent Assembly Is Dead: Elect Concon Delegates in 2004." Philippine Daily Inquirer, January 25.

Rood, Steven. 2002. "Elections as Complicated and Important Events in the Philippines." In John Fuh-Sheng Hsieh and David Newman, eds., How Asia Votes. New York: Chatham House Publishers.

Rueschemeyer, Dietrich, Evelyne Huber Stephens, and John D. Stephens. 1992. Capitalist Development and Democracy. Chicago: University of Chicago Press.

Salamanca, Bonifacio. 1984 [1968]. The Filipino Reaction to American Rule, 1901-1913. Quezon City: New Day Publishers.

Shalom, Stephen Rosskamm. 1986. The United States and the Philippines: A Study of Neocolonialism. Quezon City: New Day Publishers.

Shantz, Arthur Alan. 1972. "Political Parties: The Changing Foundations of Philippine Democracy." Ph.D. diss., University of Michigan.

Shefter, Martin. 1994. Political Parties and the State: The American Historical Experience. Princeton, NJ: Princeton University Press.

Sidel, John Thayer. 1999. Capital, Coercion, and Crime: Bossism in the Philippines. Stanford: Stanford University Press.

Silliman, G. Sidney, and Lela Garner Noble, eds. 1998. NGOs, Civil Society, and the Philippine State: Organizing for Democracy. Quezon City: Ateneo de Manila University Press.

Stanley, Peter W. 1974. A Nation in the Making: The Philippines and the United States, 1899-1921. Cambridge, MA: Harvard University Press.

Steinberg, David Joel. 1967. Philippine Collaboration in World War II. Manila: Solidaridad Publishing House.

. 2000. The Philippines: A Singular and a Plural Place, 4th ed. Boulder: Westview. 
Stepan, Alfred, and Cindy Skach. 1993. "Constitutional Frameworks and Democratic Consolidation: Parliamentarism Versus Presidentialism." World Politics (October): 1-22.

Tancangco, Luzviminda. 1988. "The Electoral System and Political Parties in the Philippines." In R. De Guzman and M. Reforma, eds., Government and Politics in the Philippines. Singapore: Oxford University Press, pp. 77-112.

Thompson, Mark R. 1995. The Anti-Marcos Struggle: Personalistic Rule and Democratic Transition in the Philippines. New Haven, CT: Yale University Press.

Velasco, Djorina, and Agustin Martin G. Rodriguez. 1998. Democracy Rising? The Trials and Triumphs of the 1998 Party List Elections. Manila: Institute of Politics and Governance.

Weekley, Kathleen. 2000. "What Kind of Populism Is That? The Politics of the Estrada Presidency." Paper presented to the annual meetings of the Association for Asian Studies, San Diego, California, March 9-12.

Wurfel, David. 1988. Filipino Politics: Development and Decay. Ithaca, NY: Cornell University Press. 